\title{
Manager Tenure - Real Estate Mutual Fund (REMF) Versus Equity Mutual Fund Performance
}

\author{
James L. Kuhle, California State University, USA
}

\begin{abstract}
Historically, mixed evidence has been reported suggesting that mutual fund managers exhibit superior returns based on the length of their tenure. Further, the result of tenure performance for real estate mutual fund managers has been reported with mixed results. Therefore, it is the purpose of this research to consider the effect of management tenure on the overall performance of various classes of equity mutual funds, including those funds that invest exclusively in real estate assets. These results are studied over periods of three, five, and ten-year manager tenure to determine if there is significantly better performance among various tenure groups.
\end{abstract}

Keywords: Real Estate Mutual Funds; Real Estate Mutual Fund Performance; Manager Tenure

\section{INTRODUCTION AND PURPOSE}

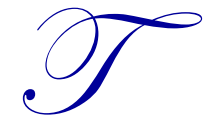

he purpose of this paper is to analyze the effects of manager tenure on Real Estate Mutual Fund (REMF) performance and to determine if the REMFs outperform six different categories of other equity mutual funds. Human capital theory predicts that factors - like education and experience improve skill sets and, ultimately, performance. On the other hand, capital market theory suggests that these variables may be irrelevant in the overall performance of mutual funds. This study analyzed over 1,600 mutual funds during the period January 2003 to January 2012 by calculating risk-adjusted return and then comparing that return to manager tenure in an effort to determine if there was a statistically significant difference in overall risk-adjusted return, first among mutual funds that invest in real estate (REMFs) and secondly, if the REMFs performed better than six other major classes of equity mutual funds; i.e., Small Growth, Mid-Cap, Large Growth, Small Value, Health Care, and Small Blend.

\section{LITERATURE REVIEW}

Historic mutual fund performance has been a topic among many academics, with most researchers concentrating on equity mutual funds. In the seminal study of mutual fund performance, Jensen (1968) developed the risk-adjusted Jensen alpha and found that equity funds tend to exhibit negative risk-adjusted performance, on average, over the period 1945-65. Elton, Gruber, Das and Hlavka (1993) examined mutual fund returns over the 1965-84 period and also found negative average performance. Further, they found that equity fund performance was negatively related to the magnitude of expense ratios and the level of portfolio trading measured by turnover.

Carhart (1997) further explored the persistence in mutual fund performance originally documented by Elton, Gruber, Das, and Blake (1996). With a sample of equity mutual funds from the period 1962-93, Carhart found that most of the persistence in performance was concentrated in poor performers. It was concluded that poor performing funds tend to continue performing poorly. Carhart further reaffirmed a negative relationship between performance and expense ratios and fund turnover.

The superior performance of real estate assets has been debated over the last 20+ years. Kuhle, Walther, and Wurtzebach (1986), Titman and Warga (1986), Goebel and Kim (1989), Chan, Hendershott, and Sanders (1990), Glascock (1991), and Martin and Cook (1991) all focused on the performance of REITs relative to other 
publicly traded investments. Using a variety of performance measures, these studies found little or no evidence of superior performance for REITs over other common stock investments.

Redding (2006) examined the TIAA Real Estate Account for mispricing problems among real estate mutual funds. Redding concludes that real estate fund managers face a challenge computing daily NAVs, given the large holdings of real estate, for which daily valuations are not practical. The resulting return predictability means that some fund investors profit at the expense of other shareholders. In this particular study, it was found that some longterm investors suffered a loss, which can be roughly estimated as one-quarter percentage point annually due to inaccurately calculated portfolio values. Managers of real estate funds can alleviate this problem by using information in recent property appraisals to update the carrying value of all properties in the portfolios.

There are relatively few academic studies solely devoted to REMFs. Thus far, the empirical evidence is mixed. First, Kallberg, Liu, and Trzcinka (2000) provide evidence of superior performance by a sample of 44 REMFs from 1986 to 1998. Contrary to previous studies of mutual funds, they provide evidence in favor of active fund management. They find that both standard and time-varying alphas are significantly positive and positively correlated to assets and turnover. Lin and Yung (2004) evaluate the performance of REMFs from 1993 to 2001 and they find that REMFs do not outperform either the stock market or the real estate market indices.

With respect to the under or over performance of Real Estate Mutual Funds (REMFs) based on manager tenure, a number of studies have been performed around the periphery of this issue. Costa, Jakob, and Porter (2006) suggest that market direction is a major factor in mutual fund risk-adjusted performance. Using a four-factor model, results show that mutual fund managers' risk-adjusted performance is better during bear markets than bull markets. Also, significant negative risk-adjusted performance during bull markets, and largely insignificant with some significant positive risk-adjusted performance during bear markets, related to the Gulf War and the collapse of the tech bubble. Costa and Porter (2003) examined the implication of longevity of the manager and the effect on performance. The results of this research yield little evidence that extraordinary performance can be maintained. Excess returns tend to be concentrated in a few crucial years. Without regard to manager tenure, funds generating significant excess returns over a three-year base period are not likely to produce positive and significant riskadjusted excess returns in subsequent three-year periods.

Philpot and Peterson (2006) examined the effects of individual manager characteristics on real estate mutual fund (REMF) performance. Human capital theory predicts that factors - like education, experience and professional certifications - improve skill sets and therefore performance. Conversely, capital market theory suggests that these things may be irrelevant in the management of mutual funds. A total of 63 REMFs were sampled over the period 2001-2003 and equations were estimate regressing, alternatively, risk-adjusted return, market risk, and management fees on a series of fund variables and manager characteristics, including the manager's tenure, whether the fund manager holds a professional certification, whether the manager has specific real estate experience, and whether the fund is team-managed. Modest evidence is found that team-managed funds have lower risk-adjusted returns than solo-managed funds. Managers with longer tenure tend to pursue higher market risk levels and there is no relation between manager characteristics and management fees. This study considers only one cross-sectional time period. Future research might use longitudinal data. Despite real estate being a specialized field of finance, there is little, if any, support for the predictions of human capital theory that experience, education, and training result in greater performance among managers of REMFs. This paper extends prior work in mutual fund management characteristics and fund performance to real estate funds.

Finally, two specific studies deal directly with the management tenure issue. Fortin (1999) found a significant negative relationship between manager tenure and turnover and a marginally significant positive relationship between manager tenure and mutual fund size. There is no overall relationship between fund manager tenure and positive performance. Filbeck and Tompkins (2004) suggest that manager tenure influences the total return and the risk-adjusted return of mutual funds. During the time period analyzed between 1999 and 2001, the S\&P 500 Index declined 2.25\% per year and the mean return for equity mutual funds - in all three sub-categories of this study - were positive. The longest-term managers did better than the intermediate- or short-term fund managers. 


\section{SAMPLE AND RESEARCH DESIGN}

The sample for this research is based on over 800 mutual fund return data that were provided by the Morningstar Inc. database. The funds analyzed represented six different category classifications, including Real Estate, Small Growth, Mid-Cap Growth, Large Growth, Small Value, Health Care, and Small Blend mutual funds. The REMF category is composed of a total of 90 real estate mutual funds. Ex-post mean returns, along with variance and standard deviations across the six categories, were calculated to provide statistical data for comparative purposes. These statistical data were then used to calculate Z-scores to compare relative performance differences within the REMF category, as well as among the remaining six categories. In addition, the results of the statistical analysis were also compared to the S\&P 500 Index. Further, return and comparative statistics were calculated for three different time periods - three, five and ten years from March 2003 to March, 2012.

Table 1 provides the year-to-date returns, standard deviations, sample size, and the risk-adjusted factors for the seven mutual fund categories. The time periods cover tenure for the last three, five, and ten years.

Table 1: Average Returns, Standard Deviation, Sample Size, and Risk/Return Ratios

\begin{tabular}{|c|c|c|c|}
\hline \multirow[t]{2}{*}{ Fund Type } & \multicolumn{3}{|c|}{ Time of Tenure } \\
\hline & Three-year & Five-year & Ten-year \\
\hline \multicolumn{4}{|l|}{ REMFs ( T 1.1) } \\
\hline Average Return & 25.8957 & -1.7191 & 11.1829 \\
\hline Standard Deviation & 5.6616 & 1.3324 & 3.3342 \\
\hline Sample Size & 49 & 34 & 7 \\
\hline Std. Dev./Average & 0.2186 & -0.775 & 0.2982 \\
\hline \multicolumn{4}{|l|}{ Small Growth (T 1.2) } \\
\hline Average & 25.9103 & 4.0836 & 6.8285 \\
\hline Standard Deviation & 3.863 & 1.687 & 0.8584 \\
\hline Sample Size & 149 & 113 & 20 \\
\hline Std. Dev./Average & 0.1491 & 0.4179 & 0.1257 \\
\hline \multicolumn{4}{|c|}{ Mid-Cap Growth (T 1.3) } \\
\hline Average & 25.3884 & 4.9 & 7.3316 \\
\hline Standard Deviation & 3.7683 & 1.5717 & 1.6285 \\
\hline Sample Size & 171 & 113 & 32 \\
\hline Std. Dev./Average & 0.1484 & 0.3208 & 0.2221 \\
\hline \multicolumn{4}{|l|}{$S \& P 500$} \\
\hline Average Return & 25.65 & 2.44 & 3.92 \\
\hline \multicolumn{4}{|l|}{ Small Value (T 1.4) } \\
\hline Average & 22.3 & 3.5 & 9.9 \\
\hline Standard Deviation & 2.216 & 5.5619 & 1.0263 \\
\hline Sample Size & 25 & 50 & 26 \\
\hline Std. Dev./Average & 0.0992 & 1.6101 & 0.1117 \\
\hline \multicolumn{4}{|l|}{ Large Growth (T 1.5) } \\
\hline Average & 16.6 & 2.9 & 3.3 \\
\hline Standard Deviation & 4.4901 & 0.9263 & 1.052 \\
\hline Sample Size & 150 & 142 & 98 \\
\hline Std. Dev./Average & 0.2701 & 0.3167 & 0.321 \\
\hline \multicolumn{4}{|l|}{ Health Care (T 1.6) } \\
\hline Average & 12.9 & 5.1 & 5.5 \\
\hline Standard Deviation & 3.9522 & 1.5089 & 2.4312 \\
\hline Sample Size & 119 & 22 & 25 \\
\hline Std. Dev./Average & 0.3057 & 0.2942 & 0.4385 \\
\hline \multicolumn{4}{|l|}{ Small Blend (T 1.7) } \\
\hline Average & 18.3 & 1.4 & 8.4 \\
\hline Standard Deviation & 4.2526 & 0.7707 & 1.7466 \\
\hline Sample Size & 173 & 97 & 29 \\
\hline Std. Dev./Average & 0.2326 & 0.5447 & 0.2073 \\
\hline
\end{tabular}


Tables 2 through 4 provide Z-scores for the seven different mutual fund categories. The Z-score measures the probability that the mean returns between two samples of return data are significantly different from one another. In column one (REMF), the comparison is made between the mean return data of the REMF category versus each of the other mutual fund categories. Each table represents a specific manager tenure period. Hence, Table 2 presents the Z-score calculations for manager tenure of three years. Table 3 presents the Z-score calculations for manager tenure of five years, and Table 4 presents the Z-score values for manger tenure of ten years.

Table 2: Z-scores Among the Mutual Fund Categories with Three-year Tenure

\begin{tabular}{|l|c|c|c|c|c|c|c|}
\hline & REMF & $\begin{array}{c}\text { Small } \\
\text { Growth }\end{array}$ & $\begin{array}{c}\text { Mid-cap } \\
\text { Growth }\end{array}$ & $\begin{array}{c}\text { Large } \\
\text { Growth }\end{array}$ & $\begin{array}{c}\text { Small } \\
\text { Value }\end{array}$ & $\begin{array}{c}\text { Health } \\
\text { Care }\end{array}$ & $\begin{array}{c}\text { Small } \\
\text { Blend }\end{array}$ \\
\hline REMF & & -0.017 & 0.59 & $10.44^{*}$ & $3.85^{*}$ & $14.63^{*}$ & $8.74^{*}$ \\
\hline Small Growth & 0.017 & & 1.22 & $19.17^{*}$ & $6.65^{*}$ & $26.99^{*}$ & $16.87^{*}$ \\
\hline Mid-cap Growth & -0.59 & -1.22 & & $18.79^{*}$ & $5.75^{*}$ & $26.92^{*}$ & $16.42^{*}$ \\
\hline Large Growth & $-10.44^{*}$ & $-19.17^{*}$ & $-18.79^{*}$ & & $-9.95^{*}$ & $7.18^{*}$ & $-3.38^{*}$ \\
\hline Small Value & $-3.85^{*}$ & $-6.65^{*}$ & $-5.75^{*}$ & $9.95^{*}$ & & $16.46^{*}$ & $7.42^{*}$ \\
\hline Health Care & $-14.63^{*}$ & $-26.99^{*}$ & $-26.92^{*}$ & $-7.18^{*}$ & $-16.46^{*}$ & & $-11.02^{*}$ \\
\hline Small Blend & $-8.74^{*}$ & $-16.87^{*}$ & $-16.42^{*}$ & $3.38^{*}$ & $-7.42^{*}$ & $11.02^{*}$ & \\
\hline
\end{tabular}

*statistically significant at the .01 level (critical $\mathrm{Z}$ value of 2.33 )

Table 3: Z-scores Among the Mutual Fund Categories with Five-year Tenure

\begin{tabular}{|l|c|c|c|c|c|c|c|}
\hline & REMF & $\begin{array}{c}\text { Small } \\
\text { Growth }\end{array}$ & $\begin{array}{c}\text { Mid-cap } \\
\text { Growth }\end{array}$ & $\begin{array}{c}\text { Large } \\
\text { Growth }\end{array}$ & $\begin{array}{c}\text { Small } \\
\text { Value }\end{array}$ & $\begin{array}{c}\text { Health } \\
\text { Care }\end{array}$ & $\begin{array}{c}\text { Small } \\
\text { Blend }\end{array}$ \\
\hline REMF & & $-20.86^{*}$ & $-24.32^{*}$ & $-19.24^{*}$ & $-6.32^{*}$ & $-17.35^{*}$ & $-12.98^{*}$ \\
\hline Small Growth & $20.86^{*}$ & & $-3.76^{*}$ & $6.56^{*}$ & 0.78 & $-2.91^{*}$ & $15.08^{*}$ \\
\hline Mid-cap Growth & $-24.32^{*}$ & $20.86^{*}$ & & $11.82^{*}$ & 1.09 & -0.65 & $20.83^{*}$ \\
\hline Large Growth & $19.24^{*}$ & $-6.56^{*}$ & $-11.82^{*}$ & & -0.67 & $-6.66^{*}$ & $13.69^{*}$ \\
\hline Small Value & $6.32^{*}$ & -0.78 & -1.81 & 0.67 & & -1.97 & $2.58^{*}$ \\
\hline Health Care & $17.35^{*}$ & $2.91^{*}$ & 0.65 & $6.66^{*}$ & 1.97 & & $11.22^{*}$ \\
\hline Small Blend & $12.98^{*}$ & $-15.08^{*}$ & $-20.83^{*}$ & $-13.69^{*}$ & $-2.58^{*}$ & $-11.22^{*}$ & \\
\hline
\end{tabular}

*statistically significant at the .01 level (critical $\mathrm{Z}$ value of 2.33 )

Table 4: Z-scores Among the Mutual Fund Categories with Ten-year Tenure

\begin{tabular}{|l|c|c|c|c|c|c|c|}
\hline & REMF & $\begin{array}{c}\text { Small } \\
\text { Growth }\end{array}$ & $\begin{array}{c}\text { Mid-cap } \\
\text { Growth }\end{array}$ & $\begin{array}{c}\text { Large } \\
\text { Growth }\end{array}$ & $\begin{array}{c}\text { Small } \\
\text { Value }\end{array}$ & $\begin{array}{c}\text { Health } \\
\text { Care }\end{array}$ & $\begin{array}{c}\text { Small } \\
\text { Blend }\end{array}$ \\
\hline REMF & & $3.42^{*}$ & $4.95^{*}$ & $6.54^{*}$ & 0.997 & $4.18^{*}$ & 2.12 \\
\hline Small Growth & $-3.42^{*}$ & & -1.45 & $16.19^{*}$ & $-11.08^{*}$ & $2.46^{*}$ & $-4.24^{*}$ \\
\hline Mid-cap Growth & $-4.95^{*}$ & 1.45 & & $13.21^{*}$ & -7.34 & $3.16^{*}$ & $-2.52^{*}$ \\
\hline Large Growth & $-6.54^{*}$ & $-16.19^{*}$ & $-13.21^{*}$ & & $-29.15^{*}$ & $-4.56^{*}$ & $-15.08^{*}$ \\
\hline Small Value & -0.997 & $11.08^{*}$ & $7.34^{*}$ & $29.16^{*}$ & & $8.30^{*}$ & $3.89^{*}$ \\
\hline Health Care & $-4.18^{*}$ & $-2.46^{*}$ & $-3.16^{*}$ & $4.56^{*}$ & $-8.30^{*}$ & & $-4.93^{*}$ \\
\hline Small Blend & -2.12 & $4.24^{*}$ & $2.52^{*}$ & $15.08^{*}$ & $-3.89^{*}$ & $4.93^{*}$ & \\
\hline
\end{tabular}

*statistically significant at the .01 level (critical $\mathrm{Z}$ value of 2.33 )

\section{RESULTS}

Consider the results within the REMF (T1.1) category only. In comparing the last three years' REMF results with that of the S\&P 500, it is clear that there is no significant difference in the returns (i.e., 25.89 vs. 25.65). Further, if the results for the five-year tenure category are compared to the S\&P 500, the REMF category actually underperformed in comparison to the S\&P 500. Finally, comparing the ten-year record of returns for the REMF category indicates that returns were substantially greater than the S\&P 500. If the data are compared crosssectionally, then the results indicate that the return was greatest for the shorter three-year tenure, but the ten-year tenure results produced the largest difference between overall performances when compared to the S\&P 500. This suggests that length of tenure does have an impact on overall performance when the S\&P 500 is used as the benchmark. 
Next, consider the comparison between the REMF category and the Small Growth category. The three-year tenure result period indicates that similar returns for the REMF (25.89\%) versus Small Growth (25.91\%) are virtually the same. The five-year tenure result indicates that the managers of the Small Growth (4.08\%) mutual fund category did substantially better than the REMF $(-1.72 \%)$ managers. Finally, the ten-year category reveals that the REMF (11.18\%) category performed significantly better than the Small Growth category (6.83\%).

When compared to the next mutual fund category, the results indicate that for the three-year tenure time period, the REMF $(25.89 \%)$ category slightly outperformed the Mid-Cap (25.39\%). For the five-year tenure time period, REMF (-1.72\%) underperformed versus the Mid-Cap (4.90\%) category. The ten-year tenure time frame, however, yielded different results. The REMF (11.18\%) outperformed the Mid-Cap (7.33\%) and was statistically significant with a Z-score of 4.952 .

Next, consider the comparison between the REMF (25.89\%) category and the Large Growth mutual fund category. For the first three-year tenure period, the REMF category statistically outperformed the Large Growth $(16.63 \%)$ with a Z-score of 10.440 . For the five-year tenure category, the Large Growth (2.93\%) was statistically better than the REMF (-1.72\%) category. For the five-year tenure time period, the REMF (11.18\%) category was statistically greater than that of the Large Growth (3.28\%) category.

The REMF category was then compared to the Small Value mutual fund category. For the three-year tenure time period, the REMF (25.89\%) category scored statistically higher than the return of the Small Value (22.35\%) category. This difference was statistically significant with a calculated Z-score of 3.847. For the five-year tenure time horizon, the REMF (-1.72\%) statistically underperformed the Small Value (3.45\%) category. The difference was again significant with a Z-score of -6.316 . The ten-year tenure time horizon yielded different results when compared to the Small Value mutual fund category. The REMF (11.18\%) category outperformed the Small Value $(9.91 \%)$ category; however, the difference was not statistically significant, yielding a Z-score of only .997 .

The REMF category was then compared to the Health Care category and similar results were obtained. The three-year tenure time period indicated that the REMF category (25.89\%) outperformed the Health Care (12.93\%) mutual fund category. This difference was statistically significant with a calculated Z-score of 14.634. Again, the five-year tenure time period yielded different results. The REMF (-1.72\%) return was statistically lower than that of the Health Care $(5.13 \%)$ category. However, the ten-year tenure category indicates that the REMF (11.18\%) category statistically outperformed the Health Care (5.54\%) category with a Z-score of 14.634.

The final statistical comparison was made between the REMF category and the Small Blend mutual fund category. The three-year tenure time frame yielded results that were statistically significant in favor of the REMF (25.89\%) versus the Small Blend (18.28\%). The five-year tenure category again indicates a reversal of fortunes for the REMF $(-1.72 \%)$ category versus Small Blend $(1.42 \%)$, which is statistically significant with a Z-score of 12.976. Finally, the ten-year tenure time period yields significantly different results for the REMF category. The REMF (11.18\%) category significantly outperforms Small Blend $(8.43 \%)$ but is not statistically significant with a Zscore of 2.119 .

\section{SUMMARY, IMPLICATIONS, AND CONCLUSIONS}

Perhaps the best way to summarize the data in this study is to consider the top four performers with each of the three tenure categories. Tables 5 and 6 summarize these results.

As depicted in Table 5, based on returns only during the three-year tenure, the Small Growth category ranked number one with an average return of $25.91 \%$, followed by the REMF category with a return of $25.89 \%$ almost identical. The Mid-Cap category was a close third with a return of $25.39 \%$, followed by the Small Value category with $22.35 \%$. 
Table 5: Summary of the Top Four Performing Mutual Fund Categories for the Three, Five, and Ten-Year Tenure Periods Based on Return Only

\begin{tabular}{|c|l|l|l|}
\hline Rank & Three-year Tenure Period & Five-year Tenure Period & \multicolumn{1}{c|}{ Ten-year Tenure Period } \\
\hline 1 & Small Growth & Health Care & REMF \\
\hline 2 & REMF & Mid-Cap Growth & Small Value \\
\hline 3 & Mid-Cap Growth & Small Growth & Small Blend \\
\hline 4 & Small Value & Small Value & Mid-Cap Growth \\
\hline
\end{tabular}

During the five-year tenure, the REMF category did not even finish in the top four among the seven various mutual fund categories. In essence, during the five-year tenure period, the REMF category was the only one to exhibit an overall negative return. All of the other six categories of mutual funds had a positive return value. This can most likely be explained with the relative collapse of the housing and real estate markets over the last five years - since 2007. While the real estate collapse has had a negative impact on the economy and is reflected in much lower returns for all categories, the REMF category was especially hard hit.

During the ten-year tenure period, the REMF category ranks number one in relation to return only. The REMF category, with an average return of $11.18 \%$ overall, ranked number one. No other category had double digit returns, with the Small Value category coming close with a $9.91 \%$ overall return. Compared to the S \& P 500 return of only $3.92 \%$, the REMF category outperforms the market over this ten-year tenure period.

Table 6 incorporates the standard deviation and hence the degree of dispersion around the average returns that are reported in Table 5. The standard deviation of returns is divided by the actual average returns in determining the value of the risk ratio. Based on this risk-adjusted metric, the REMF category does not fare well. Only during the three-year tenure period does the REMF category appear in the top four - at number four. The REMF category does not appear at all during the five and ten-year tenure periods. A number of reasons seem plausible in explaining this situation.

Table 6: Summary of the Top Four Performing Mutual Fund Categories for the Three, Five, and Ten-Year Tenure Periods Based on Risk Adjusted Return

\begin{tabular}{|c|l|l|l|}
\hline Rank & \multicolumn{1}{|c|}{ 3-year Tenure Period } & \multicolumn{1}{c|}{ 5-year Tenure Period } & \multicolumn{1}{c|}{ 10-year Tenure Period } \\
\hline 1 & Small Value & Health Care & Small Value \\
\hline 2 & Mid-Cap Growth & Large Growth & Small Growth \\
\hline 3 & Small Growth & Mid-Cap Growth & Small Blend \\
\hline 4 & REMF & Small Growth & Mid-Cap Growth \\
\hline
\end{tabular}

First, it is clear that the REMF is more volatile based on the relative average standard deviation for the category (3.334\%). Only the Health Care category had a standard deviation which exceeded $2 \%$. All other categories had standard deviations which were considerably less than $2 \%$ (see Table 1 ). This increased volatility is likely due to the fact that the real estate asset over the past ten years has been more volatile than common stocks and hence, REMF's would generally tend to be more risky than mutual funds composed of common stocks.

Second, the housing and real estate collapse - starting in 2007 and 2008 - resulted in a substantial decrease in real estate asset values when compared to the stock market. Because of the more organized stock exchange, there was less volatility amongst common stocks versus real estate assets.

A number of conclusions can be drawn from the data in this study. First, it is clear that returns of REMF's are more volatile and, as a result, tend to be higher in the long run when compared to the other mutual fund categories presented in this study. Second, it does appear, based on returns only, that the REMF category outperforms the others when the managers of such funds are tenured 10 or more years. The REMF category returns are statistically significantly different from all other categories, with the exception of the Small Value category. However, even in this case, the REMF returns of $11.18 \%$ exceeded the Small Value returns of $9.91 \%$.

It is clear that this data support previous studies which verify that real estate assets have a higher degree of volatility due to a number of differences between the underlying real estate assets versus common stock. It appears that even when real estate assets are bundled in REMFs, total portfolios comprised of real estate assets (REMF's) are plagued with higher "risk." 
Finally, and most importantly, the data in this study suggest that managers of REMF's, which continue to manage those funds for ten years or longer, actually may have superior selection qualities that allow them to outperform those managers with fewer years of expertise. That being said, the study also shows no statistical difference in the risk-adjusted returns of REMF managers and those of the other fund categories. Therefore, this study would support the contention that the risk-adjusted results of the various mutual fund categories are not significantly different, suggesting that over longer periods of time, excess returns decrease and are not significant.

\section{AUTHOR INFORMATION}

James L. Kuhle is Professor of Finance at the School of Business Administration, California State UniversitySacramento. He received his Ph.D. degree in Finance from the University of Texas in Austin, Texas and an MBA from the University of California in Los Angeles. His research interests include fundamental stock analysis and Real Estate Investment Trust performance. E-mail: kuhlej1@csus.edu

\section{REFERENCES}

1. $\quad$ Carhart, M., On Persistence in Mutual Fund Performance, The Journal of Finance, 1997, 52-82.

2. Chan, K. C., P. H. Hendershott, and A. B. Sanders, Risk and Return on Real Estate: Evidence from Equity REITs, Journal of the American Real Estate and Urban Economics Association, 1990, 18, 431-52.

3. Costa, Bruce A., Jakob, Keith, Porter, Gary E. Mutual Fund Performance and Changing Market Trends 1990-2001: Does Manager Experience Matter? The Journal of Investing, Summer 2006, 79-86.

4. Costa, Bruce A., and Porter, Gary E. Mutual Fund Managers: Does Longevity Imply Expertise? Journal of Economics and Finance, Summer 2003, Vol. 27, No. 2, 224-235.

5. Elton, E. J., M. J. Gruber, S. Das, and M. Hlavka, Efficiency with Costly Information: A Reinterpretation of Evidence from Managed Portfolios, Review of Financial Studies, 1993, 6, 122.

6. $\quad$ Elton, E. J., M. J. Gruber, S. Das, and C. R. Blake, The Persistence of Risk-Adjusted Mutual Fund Performance, Journal of Business, 1996, 69, 133-57.

7. Filbeck, Greg, and Tompkins, Daniel L. Management Tenure and Risk-Adjusted Performance of Mutual Funds. The Journal of Investing, Summer, 2004, 72-80.

8. Fortin, Rich, Michelson, Stuart, and Jordan-Wagner, James. Does Mutual Fund Manager Tenure Matter? Journal of Financial Planning. August 1999. Vol 12, No. 7. Pp. 72-79.

9. Glascock, J. L., Market Conditions, Risk and Real Estate Portfolio Returns: Some Empirical Evidence, Journal of Real Estate Finance and Economics, 1991, 4, 367-73.

10. Goebel, P. R. and K. S. Kim, Performance Evaluation of Finite-- Life Real Estate Investment Trusts, Journal of Real Estate Research, 1989, 4, 57-69.

11. Jensen, M., The Performance of Mutual Funds in the Period 1945-64, Journal of Finance, 1968, 23, 389416.

12. Kallberg, J. G., C. L. Liu, and C, Trzcinka. The Value Added from Investment Managers: An Examination of Funds of REITs, Journal of Financial and Quantitative Analysis, 2000, 35, 387-408.

13. Kuhle, J. L., C. H. Walther, and C. H. Wurtzebach, Financial Performance of Real Estate Investment Trusts, Journal of Real Estate Research, 1986, 1:1, 67-75.

14. Lin, C.Y. and K, Yung, Real Estate Mutual Funds: Performance and Persistence, Journal of Real Estate Research, 2004, 26, 69-93.

15. Martin, J. D. and D. O. Cook, A Comparison of the Recent Performance of Publicly Traded Real Property Portfolios and Common Stock, Journal of the American Real Estate and Urban Economics Association, 1991, 19, 184-212.

16. Philpot, James and Craig A. Peterson, Manager Characteristics and Real Estate Mutual Fund Returns, Risk and Fee, Managerial Finance. Patrington: 2006. Vol. 32, Issue 12; pg. 988.

17. Redding, Lee S., Persistent Mispricing in Mutual Funds: The Case of Real Estate, Journal of Real Estate Portfolio Management, 2006, Vol. 12, Issue 3, 223-233.

18. Russell, Philip S., Do the Stars Foretell the Future/: The Performance of Morning Star Ratings. Journal of American Academy of Business. September 2006, Vol. 10, No. 1. pp. 85-89.

19. Titman, S. and A. Warga, Risk and the Performance of Real Estate Investment Trusts: A Multiple Index Approach, Journal of the American Real Estate and Urban Economics Association, 1986, 14, 414-31. 


\section{NOTES}

